\title{
INTERPRETASI MAKNA PADA WARUNG KOPI ACEH Studi Kasus: Warung Kopi Solong di Banda Aceh
}

\author{
Riza Aulia Putra ${ }^{1}$, Agus S. Ekomadyo ${ }^{2}$ \\ ${ }^{1,2}$ Sekolah Arsitektur, Perencanaan dan Pengembangan Kebijakan, Institut Teknologi Bandung \\ Jl. Ganesha No. 10 Bandung 40132 \\ email: ${ }^{1}$ rizaauliaputra@ymail.com, ${ }^{2}$ agus_ekomadyo@yahoo.co.id
}

\begin{abstract}
Abstrak
Tradisi berkumpul untuk silaturahmi pada masyarakat Aceh sudah lama terbentuk. Warung kopi merupakan salah satu artefak dari tradisi atau budaya berkumpul pada masyarakat Aceh. Warung kopi merupakan tempat terjadinya interaksi sosial dan berbagai aktivitas lainnya. Salah satu contoh kasus yang diambil yaitu pada warung kopi Solong yang berada di Kota Banda Aceh. Tujuan penulisan ini adalah untuk menelusuri ruh atau genius loci yang membuat warung kopi Aceh terus hidup dan berkembang. Dengan menggunakan pemikiran dari Norberg-Schulz maka akan dikaji dan ditelusuri lebih jauh mengenai citra, ruang dan karakter yang membentuk genius loci pada warung kopi Aceh sehingga membuat masyarakat Aceh memilih warung kopi sebagai tempat melakukan berbagai aktivitas dan interaksi sosial. Dengan mengkaji unsur tersebut akan didapatkan faktor-faktor yang mempengaruhi sebuah tempat yaitu makna, identitas dan sejarah tempat tersebut.
\end{abstract}

Kata kunci: tempat, ruang interaksi, genius loci, warung kopi

\begin{abstract}
Title: The Interpretation of Meaning in Aceh Coffee Shop

The gathering tradition in Acehnese people for silaturrahmi has long been established. A coffee shop is one of the artefacts from Aceh traditions or gathering culture for Acehnese people. Coffee shop is a place for social interaction and other various activities. One example of case that was taken is Solong Coffee shop located in the city of Banda Aceh. The purpose of this paper is to explore the spirit or genius loci that makes coffee shop in Aceh continue to live and thrive. By using the thinking of Norberg-Schulz, it will be studied and explored for more about image, space and character that create the genius loci in a Aceh coffee shop to attract the Acehnese people to choose the coffee shop as a place to do their various activities and social interaction. Reviewing these elements will obtain many factors that affect a place such as the meaning, identity and history of the place.
\end{abstract}

Keywords: place, interaction space, genius loci, coffee shop

\section{Pendahuluan}

Kopi merupakan salah satu ikon bagi masyarakat Aceh. Hal ini dikarenakan keunikan dan karakter yang dimiliki oleh kopi Aceh itu sendiri. Aceh telah dikenal dengan kopinya yang khas. Potensi kopi Aceh yang cukup baik ini terus berkembang hingga saat ini. Kopi menjadi media interaksi sosial antar masyarakat Aceh. Hal ini dikarenakan menikmati secangkir kopi di warung kopi telah menjadi tradisi bagi masyarakat Aceh, khususnya bagi kaum pria. Tradisi ini telah berkembang turun temurun pada masyarakat Aceh. Tradisi berkumpul dan melakukan interaksi sosial ini juga 
dipengaruhi oleh nilai-nilai keislaman yang sangat kuat pada masyarakat Aceh. Pentingnya silaturahmi menjadi poin utama sehingga membuat masyarakat Aceh sering berkumpul.

Warung kopi merupakan artefak dari tradisi atau budaya berkumpul masyarakat Aceh. Budaya berkumpul di warung kopi dalam masyarakat Aceh merupakan wujud kebudayaan berbentuk aktivitas. Aktivitas ini lahir dari kebiasaan sehari-hari yang dilakukan oleh masyarakat Aceh khususnya di kota Banda Aceh (Koentjaraningrat, 1974). Budaya berkumpul ini sudah menjadi kebiasaan turun temurun pada masyarakat Aceh. Hal ini dipengaruhi oleh nilai-nilai Islam yang begitu kuat pada kehidupan masyarakat Aceh yang mengharuskan masyarakat untuk menjaga dan menjalin silaturahmi dalam kehidupan bermasyarakat. Agama Islam memiliki pengaruh yang kuat dalam membentuk pola pikir, sikap dan perilaku masyarakat Aceh dalam kehidupan sehari-hari (Sufi, 2004). Interaksi sosial dan berbagai kegiatan lainnya seperti kegiatan politik, bisnis dan ekonomi, diskusi-diskusi ilmiah dan sebagainya dapat terjadi di warung kopi. Hal ini menjadi salah satu penyebab banyaknya jumlah warung kopi yang hadir di Aceh khususnya di kota Banda Aceh. Banda Aceh menjadi pilihan bagi para pengembang usaha dikarenakan fungsinya sebagai ibukota provinsi Aceh yang pertumbuhan ekonominya lebih berkembang dibandingkan daerah lainnya di provinsi Aceh.

Warung kopi telah membentuk tempat dan makna bagi masyarakat Aceh. Masyarakat Aceh lebih memilih warung kopi dari pada tempat lainnya sebagai ruang interaksi sosial dan aktivitas lainnya. Kondisi ini dapat berlangsung karena adanya ruh atau spirit yang menjaga identitas atau karakter dari kopi Aceh yang oleh Norberg-Schulz disebut dengan genius loci sehingga eksistensi dari warung kopi dapat terus bertahan dan berkembang. Genius loci dapat tercipta dari kemampuan masyarakat suatu daerah untuk menerima pengaruh luar secara selektif dan melalui proses kreatif melahirkan ciptaan baru yang unik dan tidak terdapat dalam wilayah asal budaya tersebut (Arif, 2008). Genius loci merujuk pada kecerdasan lokal yang dibangun antara masyarakat pada lingkungan fisik yang mewadahi kegiatannya. Dengan pendekatan genius loci, maka setiap tempat akan dinilai maknanya bagi komunitas yang memanfaatkannya (Ekomadyo, 2012).

Melalui penelitian ini akan diungkap bagaimana makna yang terbentuk pada warung kopi sebagai identitas yang menjadi bagian sejarah bagi masyarakat Aceh. Dengan menggunakan konsep tempat (place) dari Norberg-Schulz maka akan ditinjau lebih jauh mengenai citra, ruang dan karakter yang membentuk genius loci pada warung kopi. Dengan keempat hal tersebut akan ditemukan ruh atau spirit of place pada warung kopi yang membuat warung kopi di Banda Aceh terus berkembang dan ramai dikunjungi oleh masyarakat Aceh.

\section{Metode Penelitian}

Penelitian ini menggunakan metode deskriptif kualitatif dengan memaparkan fakta dan fenomena yang ada dalam lokasi penelitian. Pengumpulan data dilakukan dengan melakukan observasi langsung untuk mengamati perilaku dan aktivitas pada warung kopi Aceh. Selain itu juga 
dilakukan wawancara berhadaphadapan (face-to-face interview) dengan manager warung kopi dan wawancara dalam kelompok (focus group interview) dengan pengunjung warung kopi. Warung kopi Aceh yang menjadi sampel pada penelitian ini adalah warung kopi Solong yang terletak di kota Banda Aceh, Aceh. Data yang telah diperoleh kemudian akan dianalisis berdasarkan pemikiran dari Norberg-Schulz mengenai konsep place (tempat) sehingga dapat diketahui faktor yang membentuk genius loci pada warung kopi Aceh.

\section{Makna dan Tempat dalam Arsitektur}

Makna (meaning) merupakan fungsi psychic (berkaitan dengan kekuatan batin) yang bergantung pada proses identifikasi dan menunjukkan sense of belonging. Makna dari setiap objek terdiri dari hubungan dengan objek yang lainnya, yang terdiri dari kumpulan-kumpulan objek. Makna akan dipengaruhi oleh faktor ekonomi, sosial, politik dan fenomena budaya lainnya. Makna yang ditemukan dalam sebuah tempat merupakan genius loci atau ruh yang menjadi pembangkit kehidupan pada tempat tersebut (Norberg-Schulz, 1980).

Tempat (place) dapat diartikan sebagai ruang yang memiliki karakter, atmosfir atau makna tertentu. Sebuah place adalah sebuah space yang memiliki suatu ciri khas tersendiri. Sebuah space akan ada kalau dibatasi sebagai sebuah void, dan sebuah space menjadi sebuah place kalau mempunyai arti dari lingkungan yang berasal dari budaya daerahnya (Zahnd, 1999).

Places diidentifikasikan dengan sesuatu yang tidak berubah. Sense of place yang terdapat didalamnya, karakter atau identitas akan relatif stabil. Hal inilah yang sering dihubungkan dengan spirif of place atau genius loci yang dikemukakan oleh Norberg-Schulz (Dovey, 2010)

Place memiliki karakter sebagai elemen pembentuknya. Karakter ini ditentukan oleh material dan keadaan formal dari place seperti kondisi tanah tempat kita berjalan, kondisi langit di atas kepala, atau yang lebih umum yaitu keadaan di sekitar place itu sendiri. Ada tiga hal yang membentuk sebuah place yaitu meaning, identity dan history. Sebuah place akan memiliki spirit of place atau yang disebut oleh Norberg-Schulz sebagai genius loci jika memiliki unsur-unsur di atas. Genius loci merupakan konsep Romawi. Menurut kepercayaan kuno Romawi setiap sesuatu yang berdiri memiliki genius, yang menjaga spirit suatu tempat (a guardian spirit). Spirit ini yang memberikan kehidupan untuk manusia dan tempat, menemani mereka dari lahir sampai kematian dan menentukan karakter mereka. Place akan kehilangan identitasnya jika faktor ekonomi, sosial, politik dan budaya tidak diwujudkan dengan menghormati genius loci. Untuk menghormati genius loci bukan berarti harus menggunakan model lama. Namun itu berarti menentukan sebuah identitas place dan menginterpretasikannya dengan berbagai cara bahkan dalam cara baru (Norberg-Schulz, 1980).

Berdasarkan pemikiran Norberg-Schulz ada empat aspek yang dapat digunakan untuk menelusuri genius loci pada suatu tempat, yaitu citra, ruang, karakter dan genius loci itu sendiri. Dengan menelusuri keempat aspek tersebut maka akan didapatkan faktorfaktor yang dapat mempengaruhi 
sebuah tempat yaitu makna, identitas dan kesejarahan tempat tersebut.

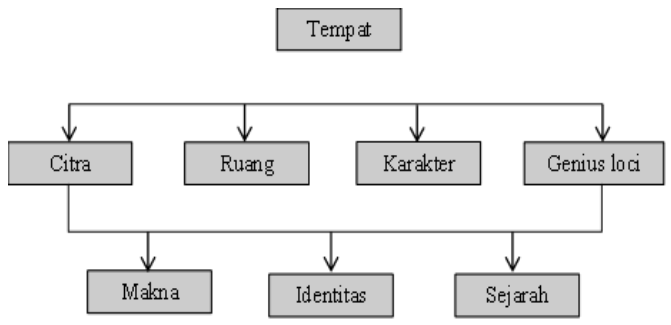

Gambar 1. Unsur-unsur untuk menelusuri genius loci pada sebuah tempat menurut Norberg-Schulz

Sumber: Norberg-Schulz, 1980

\section{Warung Kopi sebagai Artefak Budaya Masyarakat Aceh}

Budaya berkumpul di warung kopi pada masyarakat Aceh awalnya dilakukan hanya untuk menikmati secangkir kopi dan menjalin silaturahmi dengan karib kerabat. Namun pada saat ini telah terjadi perubahan dan pergesaran fungsi dari warung kopi sebagai sebuah tempat (place). Warung kopi telah menjadi multifungsi untuk berbagai keperluan seperti tempat pertemuan, membahas pekerjaan, mengerjakan tugas bagi pelajar dan mahasiswa dan sebagainya. Tidak hanya berhenti disitu, warung kopi telah berkembang menjadi destinasi wisata. Kebiasan masyarakat Aceh yang suka berkumpul di warung kopi dan banyaknya warung kopi di sepanjang jalan kota Banda Aceh membuat setiap pendatang yang mengunjungi kota Banda Aceh turut berkeinginan untuk mencoba merasakan kopi Aceh. Hal ini membuat warung kopi menjadi salah satu destinasi wisata yang dapat meningkatkan nilai pariwisata Aceh di sektor wisata kuliner.
Hidupnya warung kopi di Banda Aceh dikarenakan tingginya partisipasi dari masyarakat untuk mengunjungi dan melakukan aktivitas di warung kopi. Hal ini dipengaruhi oleh beberapa faktor seperti keunikan kopi Aceh itu sendiri, sajian kuliner khas Aceh yang disediakan, kenyamanan tempat pada warung kopi, fasilitas tambahan seperti layanan ruang meeting dan wifi, atraksi penyajian kopi Aceh oleh barista, suasana yang informal, view tertentu pada warung kopi, teman atau pengunjung yang datang pada warung kopi tersebut dan lain sebagainya. Faktor-faktor tersebut yang membuat masyarakat Aceh lebih memilih untuk melakukan berbagai aktivitas di warung kopi dibandingkan dengan di tempat atau restoran-restoran lainnya.

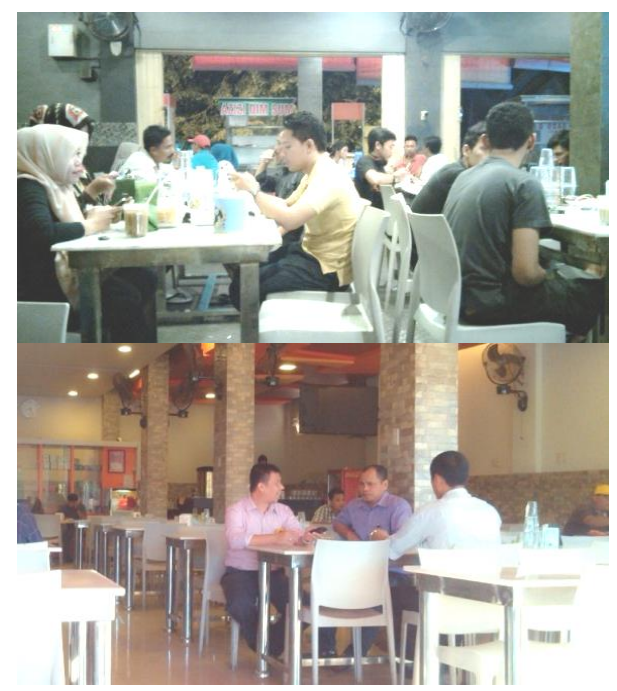

Gambar 2. Budaya/tradisi berkumpul di warung kopi

Sumber: Dokumentasi Putra, 2015

Warung kopi hadir untuk berbagai keperluan. Menerima tamu atau wisatawanpun sering dilakukan di warung kopi. Hal ini dilakukan karena kegiatan-kegiatan di warung kopi dapat dilakukan secara informal dan lebih terbuka. Secara tidak langsung ini akan berdampak pada promosi kopi aceh itu sendiri. 
Sebagai ruang interaksi sosial, warung kopi muncul dengan beragam bentuk dan gaya arsitektur, mulai dari yang berbentuk dan bergaya arsitektur tradisional atau etnik sampai yang bergaya modernpun ikut hadir. Beragam jenis bangunan warung kopi ini telah menciptakan citra tersendiri bagi kota Banda Aceh. Citra ini diperlukan sebagai salah satu yang membentuk identitas serta wajah arsitektur kota. Tanpa citra, arsitektur tidak ada (Arif, 2008).

Salah satu warung kopi yang banyak dikunjungi oleh masyarakat Aceh adalah warung kopi Solong. Warung kopi solong merupakan salah satu warung kopi yang berada di kota Banda Aceh sejak tahun 1974. Warung kopi Solong telah mendapat kepercayaan dari masyarakat karena memiliki cita rasa kopi yang sangat kuat. Disamping itu pengunjung yang datang pada warung kopi Solong juga menjadi magnet bagi pengunjung lainnya untuk datang pada warung kopi ini. Oleh karena itu, warung kopi Solong terus ramai dikunjungi oleh masyarakat Aceh dari pagi hari hingga malam hari.

Awalnya warung kopi Solong merupakan warung kopi dengan suasana konvensional yang berada di kawasan permukiman warga. Seiring dengan perkembangan waktu, warung kopi Solong terus berkembang hingga mengubah tampilannya menjadi lebih modern dan hingga saat ini telah memiliki 4 cabang di kota Banda Aceh.

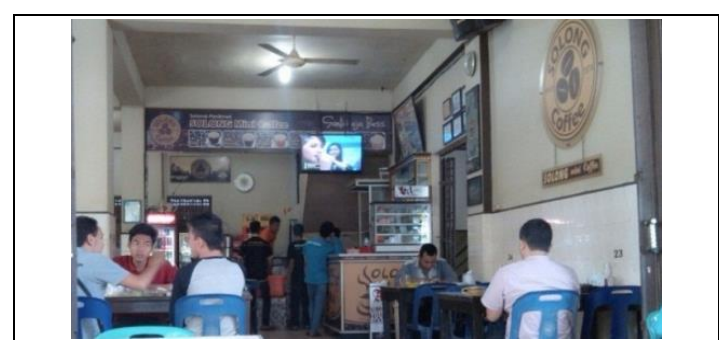

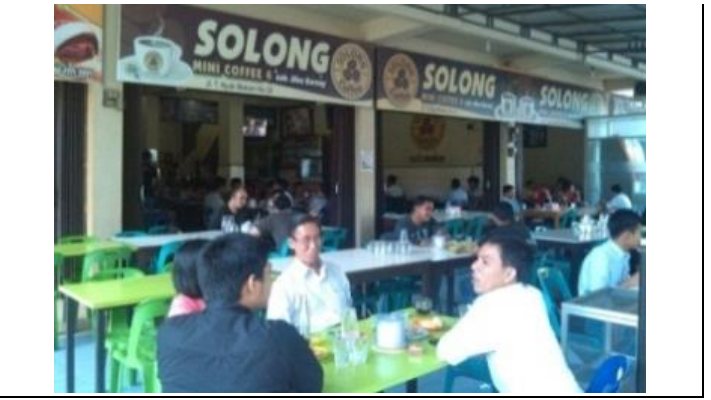

Gambar 3. Warung kopi solong dengan suasana konvensional (bentuk lama) Sumber: Dokumentasi Putra, 2015

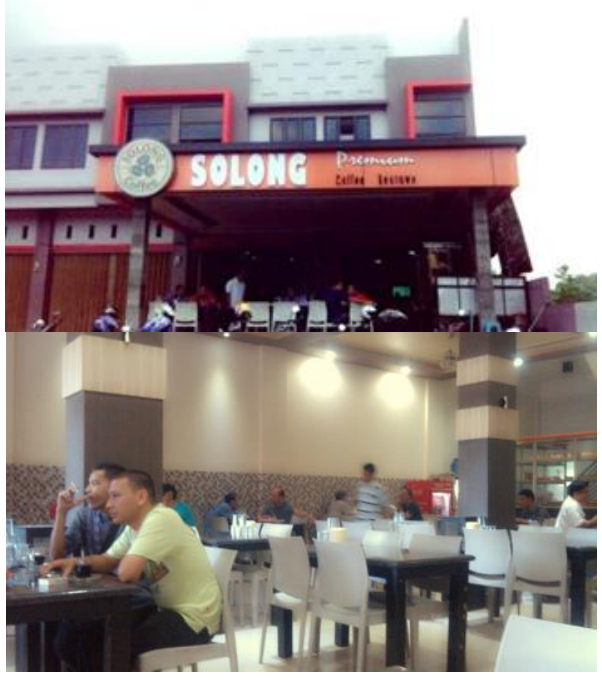

Gambar 4. warung kopi solong dengan suasana modern (bentuk baru)

Sumber: Dokumentasi Putra, 2015

Namun ada hal yang menarik pada warung kopi Solong. Meskipun warung kopi ini telah mengubah tampilannya menjadi lebih modern, namun ada hal yang unik dan masih dipertahankan sebagai ciri khas warung kopi Aceh itu sendiri, yaitu kopi dan proses penyajiannya yang khas. Kedua hal ini telah menjadi keunikan tersendiri bagi warung kopi dan menjadikannya ruh atau genius loci yang mampu menarik masyarakat Aceh untuk datang dan melakukan aktivitas di warung kopi. 

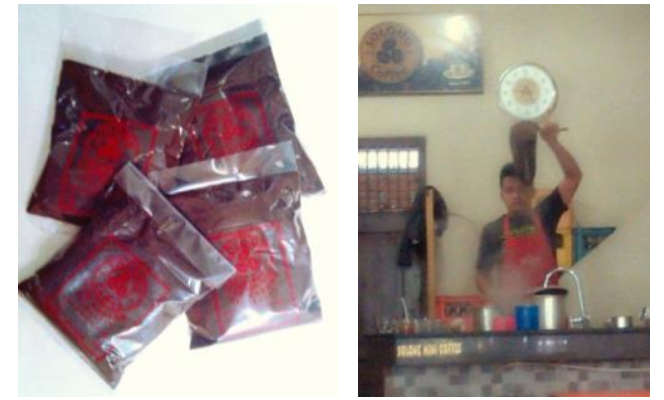

Gambar 5. Kopi Aceh dan proses penyajiannya

Sumber: Dokumentasi Putra, 2015

Citarasa kopi yang kuat dan adanya sajian khusus yang ditawarkan membuat warung kopi ini terus berkembang. Warung kopi Solong memiliki salah satu jenis minuman hasil racikan sendiri yang sangat diminati oleh masyarakat Aceh. Minuman tersebut disebut sanger yang terbuat dari campuran kopi dengan sedikit susu dan sedikit gula. Yang membedakannya dengan kopi susu biasa adalah perpaduan dan komposisi antara kopi dengan susunya. Proses penyajiannya yang khas pun juga mempengaruhi dari rasa sanger tersebut.

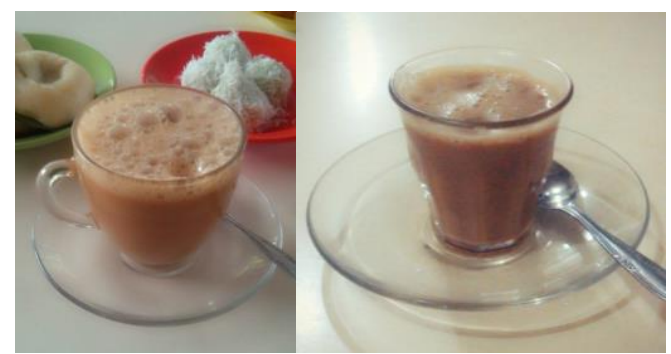

Gambar 6. Minuman sanger di warung kopi Solong

Sumber: Dokumentasi Putra, 2015

\section{Telaah Makna dan Tempat pada Warung Kopi Solong di Banda Aceh}

Warung kopi sebagai ruang interaksi sosial masyarakat kota menjadi salah satu tujuan dari masyarakat untuk saling berinteraksi. Fenomena ini tentunya berlangsung karena adanya ruh atau spirit yang ada pada warung kopi Aceh sehingga masyarakat lebih memilih untuk saling berinteraksi di warung kopi. Hal ini menyebabkan perkembangan dan pertumbuhan warung kopi di Banda Aceh terus meningkat terutama setelah terjadinya peristiwa tsunami tahun 2004 silam. Dengan menggunakan kerangka teori dari Norberg-Schultz, maka akan ditelaah makna tempat pada warung kopi solong di Banda Aceh melalui citra, ruang, dan karakter sehingga mendapatkan genius loci yang menjadi ruh atau spirit dari warung kopi tersebut.

\section{Citra Warung Kopi: Interaksi Sosial}

Masyarakat Aceh melihat warung kopi sebagai tempat untuk melakukan interaksi sosial. Dengan media secangkir kopi, mereka dapat melakukan pertemuan dan berbagai kegiatan lainnya di warung kopi. Berbagai bentuk kegiatan dan aktivitas dapat terjadi pada warung kopi di masa kini. Hal ini terjadi dikarenakan telah terjadi pergeseran makna pada fungsi tempat (place) di warung kopi. Warung kopi yang dulunya hanya didatangi oleh kaum lelaki kini tidak lagi demikian. Kaum wanitapun telah ramai mendatangi warung kopi. Hal ini disebabkan tujuan masyarakat mengunjungi warung kopi bukan semata untuk mendapatkan secangkir kopi, akan tetapi lebih kepada perilaku sosial untuk berkumpul bersama teman atau rekan kerja. Perilaku sosial ini tentu membutuhkan tempat (place). Oleh karena itu warung kopi hadir sebagai upaya penyediaan tempat untuk aktivitas interaksi sosial tersebut. Warung kopi hadir tidak lagi sebagai kebutuhan semata, melainkan telah menjadi gaya hidup dengan berbagai fasilitas penunjang yang mendukung 
seperti adanya layanan internet dan sebagainya. Namun makna inti dari warung kopi sendiri sebagai ruang sosial tidaklah hilang.

Manager warung kopi Solong (Sarbaini, 35 tahun) menjelaskan bahwa hampir seluruh pengunjung yang datang ke warung kopinya bertujuan untuk bertemu dengan teman atau relasi bisnis sambil menikmati secangkir kopi. Kopi telah menjadi media yang menarik orang untuk berinteraksi di warung kopi. Arti interaksi sosial disini tidak sebatas pada sesama masyarakat Aceh, melainkan juga interaksi terhadap masyarakat dari luar Aceh seperti wisatawan. Nilai-nilai budaya masyarakat Aceh untuk memuliakan tamu (peumulia jamee) atau melayani tamu dengan sebaik-baiknya tetap dipegang kuat oleh masyarakat Aceh. Sehingga warung kopi sebagai place menyediakan ruang untuk terjadinya interaksi sosial tersebut.

Terdapat dua jenis warung kopi Solong di Banda Aceh, yaitu warung kopi Solong bentuk lama dengan desain konvensional dan bentuk baru dengan desain yang lebih modern. Interaksi sosial terjadi pada warung kopi Solong dengan bentuk lama maupun pada warung kopi Solong dengan bentuk baru. Ini memperlihatkan bahwa warung kopi dengan desain konvensional ataupun warung kopi dengan desain modern tidak mempengaruhi pandangan masyarakat dalam melihat warung kopi sebagai tempat untuk melakukan interaksi sosial dan aktivitas lainnya.

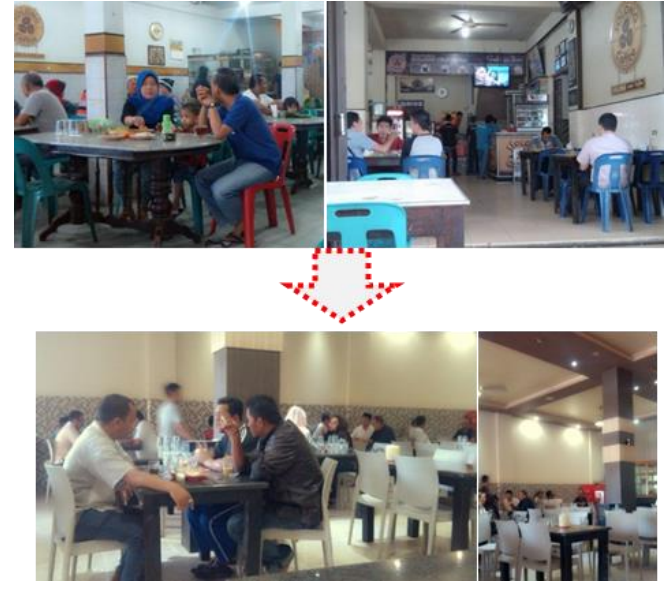

Gambar 7. Warung kopi sebagai ruang interaksi sosial pada bentuk lama (atas) dan bentuk baru (bawah)

Sumber: Dokumentasi Putra, 2015

\section{Ruang: Wadah Interaksi Sosial}

Untuk mewadahi aktivitas interaksi sosial diperlukan space atau ruang untuk kegiatan tersebut. Pada warung kopi umumnya makna ruang yang dipahami di sini dalam lingkup makna fisik. Ruang tersebut memiliki dimensi dan batasan yang jelas. Interaksi sosial terjadi pada sebuah meja dengan beberapa kursi sesuai dengan pengunjungnya.

Terdapat dua jenis interaksi yang terjadi pada warung kopi. Pertama yaitu interaksi antar sesama pengunjung. Ini merupakan interaksi utama yang melibatkan pengunjung yang satu dengan yang lainnya. Interaksi ini memiliki beragam jenis tujuan, seperti tujuan sosial, politik, ekonomi dan bisnis, serta tujuan edukasi. Disamping itu juga terdapat interaksi antar pengunjung dengan pelayan warung kopi. Interaksi ini hanya sebatas pada proses pelayanan saja. Kedua interaksi ini dapat saling bersinggungan dalam sebuah ruang. 

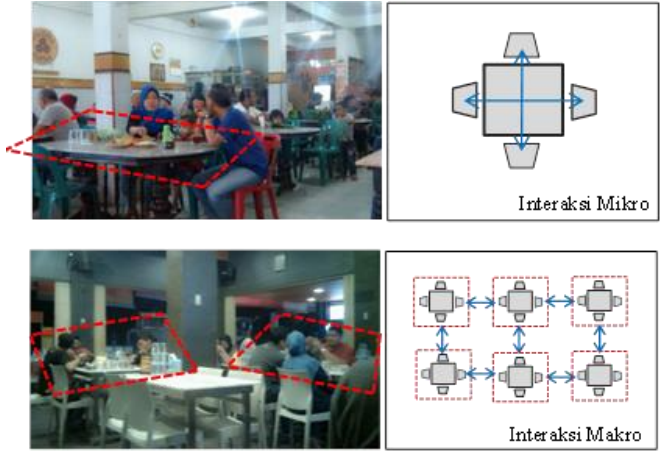

Gambar 8. Pola interaksi mikro (atas) dan makro (bawah) dalam sebuah warung kopi Sumber: Hasil analisis, 2015

Jika ditinjau dari segi besaran dan batasannya, interaksi yang terjadi pada warung kopi dapat dibedakan menjadi interaksi secara mikro dan makro. Interaksi sosial secara mikro dapat didefinisikan oleh sebuah meja dengan beberapa kursi sesuai dengan jumlah pengunjungnya. Kopi menjadi media yang mengikat interaksi tersebut. Sedangkan interaksi sosial secara makro didefinisikan sebagai interaksi yang terjadi antara beberapa interaksi mikro yang terdapat dalam warung kopi tersebut.

\section{Karakter : Keunikan Warung Kopi}

Dari penjelasan dan analisis yang dilakukan sebelumnya, terdapat keunikan dan kekhasan yang dimiliki oleh warung kopi Aceh yaitu kopi Aceh itu sendiri serta proses penyajiannya yang khas. Kedua hal ini telah menjadi karakter bagi warung kopi di Aceh. Keunikan ini merupakan bagian yang dipertahankan pada warung kopi baik pada warung kopi dengan bentuk lama maupun warung kopi dengan bentuk baru (modern).

Kopi Aceh menjadi salah satu faktor utama yang menyebabkan ramainya masyarakat mengunjungi dan melakukan aktivitas di warung kopi. Kopi Aceh memiliki cita rasa yang khas sehingga dengan kelebihan ini kopi aceh telah menjadi media pengikat untuk interaksi masyarakat. Kopi aceh juga lazim dihidangkan bersama dengan makanan-makanan ringan khas Aceh. Kopi Aceh memiliki keunikan tersendiri dibandingkan dengan kopikopi lainnya, khususnya dalam proses penyajiannya. Proses penyajian kopi Aceh telah menjadi warisan turuntemurun dan menjadi identitas bagi kopi Aceh itu sendiri. Kopi Aceh disajikan oleh seorang barista (sebutan untuk penyaji kopi) yang sudah memiliki keahlian tersebut. Keunikan ini menjadi salah satu faktor yang menjadi daya tarik bagi wisatawan yang belum pernah melihat proses penyajian kopi Aceh.

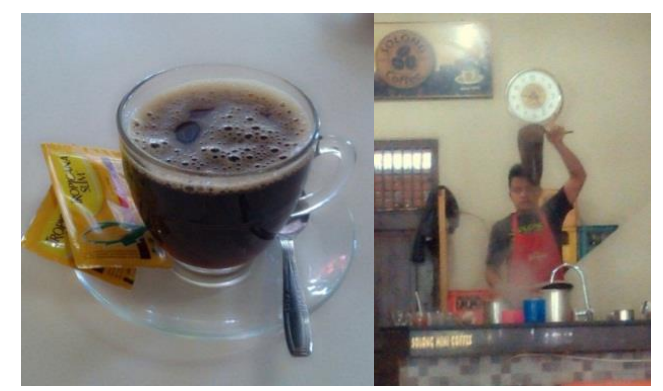

Gambar 9. Kekhasan warung kopi Aceh Sumber: Dokumentasi Putra, 2015

Meskipun warung kopi Solong hadir dalam bentuk baru yang modern, ada keunikan yang telah menjadi karakter warung kopi yang dipertahankan yaitu kopi itu sendiri dan proses penyajiannya. Dengan adanya keunikan yang kuat pada kopi Aceh dan proses penyajiannya, maka ini menciptakan genius loci yang kuat pula pada warung kopi sebagai tempat. Karakter ini memberikan eksistensi kepada warung kopi sehingga membuat masyarakat memilih warung kopi sebagai tempat untuk melakukan interaksi sosial dan berbagai aktivitas lainnya. Analisis pola interaksi pada warung kopi dapat dilihat pada tabel 1 . 
Tabel 1. Analisis interaksi pada warung kopi Aceh

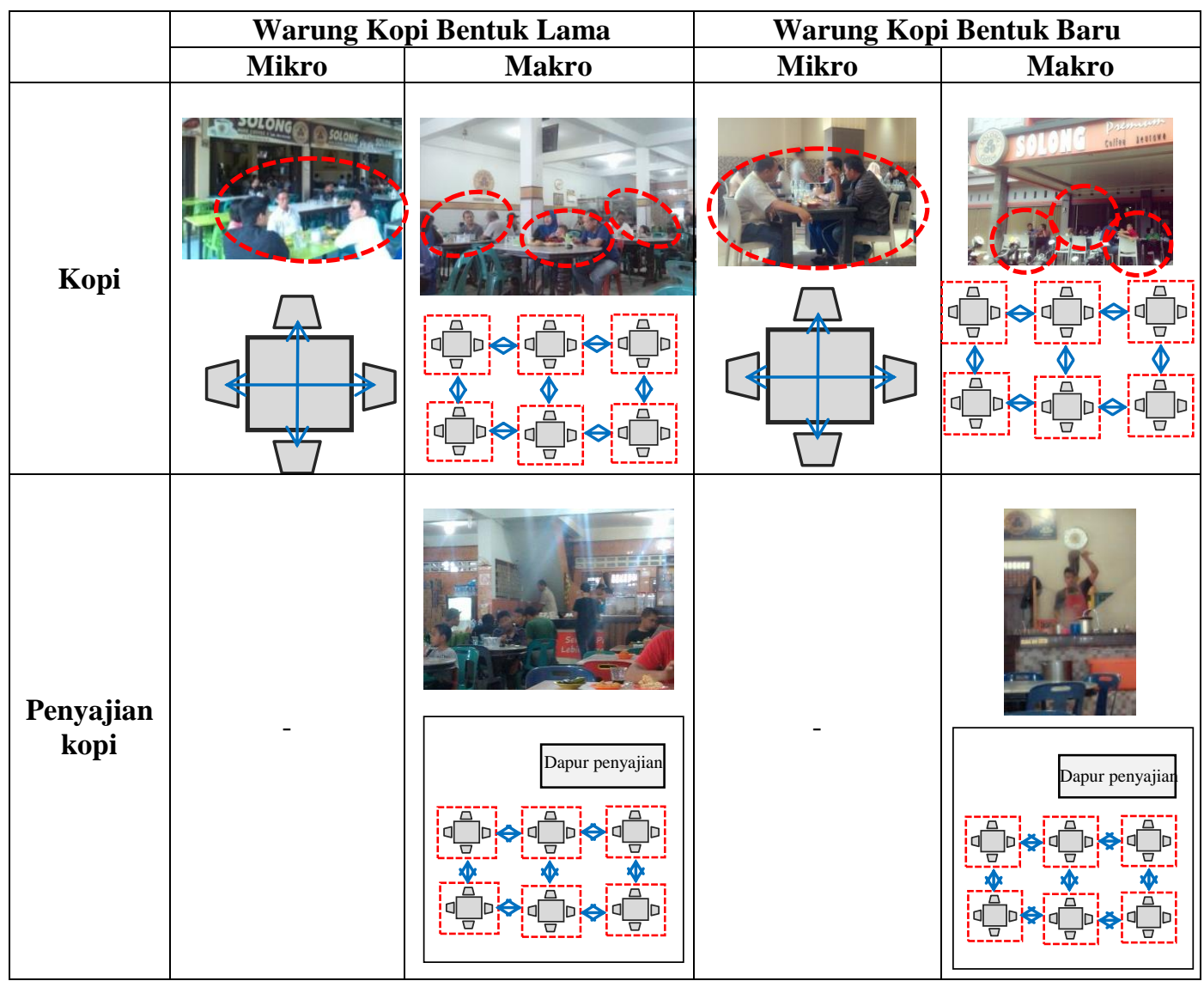

Sumber: Hasil analisis, 2015

\section{Genius Loci: Kopi sebagai Pengikat Silaturahmi}

Genius loci dapat didefinisikan sebagai ruh atau spirit pada suatu tempat yang menjaga dan membuat tempat tersebut hidup. Eksistensi warung kopi Aceh terus berkembang dikarenakan adanya genius loci yang menyebabkan ketertarikan masyarakat Aceh untuk melakukan interaksi sosial dan beragam aktivitas lainnya di warung kopi.

Genius loci pada warung kopi hadir dari perannya sebagai ruang interaksi sosial bagi masyarakat. Warung kopi menjadi wadah untuk berbagai aktivitas sosial, politik, ekonomi bahkan edukasi.
Pada warung kopi Solong di Banda Aceh, genius loci yang ditemukan adalah kopi Aceh atau kopi Solong itu sendiri dan proses penyajiannya. Kopi Solong telah memiliki citarasa yang khas sehingga telah mendapat kepercayaan dari masyarakat Aceh.

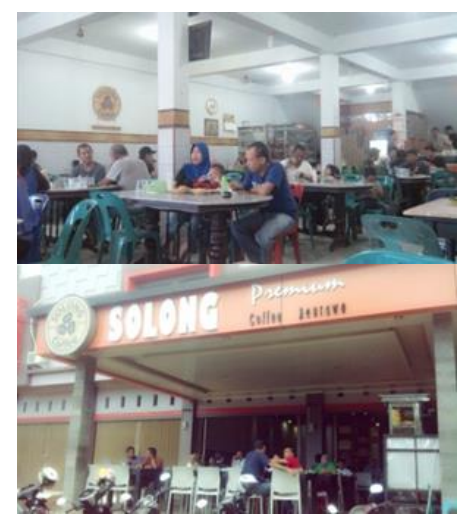

Gambar 10. Kopi sebagai genius loci pada warung kopi

Sumber: Dokumentasi Putra, 2015 
Kesukaan masyarakat Aceh terhadap kopi menjadikannya alasan untuk masyarakat berkumpul pada warung kopi. Kopi membentuk ruang interaksi, mulai dari ruang mikro, makro bahkan sampai ke ruang kota. Kopi telah menjadi sebagai media pengikat interaksi masyarakat Aceh.

\section{Kesimpulan}

Jika ditelaah melalui konsep "place" dari Norberg-Schultz maka diperlukan makna, identitas dan sejarah pada warung kopi sebagai sebuah place. Makna dalam place warung kopi terbentuk karena perannya sebagai ruang interaksi sosial atau wadah silaturahmi bagi masyarakat Aceh. Warung kopi telah menjadi tempat bagi masyarakat Aceh untuk bertukar pikiran dan melakukan berbagai kegiatan lainnya. Warung kopi telah menjadi identitas yang melambangkan simbol dari nilai-nilai perkawanan dan kekerabatan pada masyarakat Aceh. Hal ini tentunya dipengaruhi oleh sejarah pada masyarakat Aceh yang sering berkumpul untuk silaturahmi. Tradisi berkumpul pada masyarakat Aceh ini dipengaruhi oleh nilai-nilai Islam yang melekat kuat pada masyarakat Aceh.

Warung kopi di Aceh mempunyai makna, identitas dan sejarahnya tersendiri yang berbeda dengan warung kopi di daerah lainnya. Hal inilah yang membuat warung kopi Aceh memiliki karakter dan ciri khas tersendiri. Karakter ini yang menjadi ruh pada warung kopi sehingga membuat masyarakat tertarik untuk datang ke warung kopi dan menjadikan eksistensi kopi Aceh terus bertahan dan berkembang sampai saat ini.

\section{Daftar Pustaka}

Arif, K. A. (2008). Ragam citra Kota Banda Aceh. Bandung: Pustaka Bustanussalatin.

Dovey, K. (2010). Becoming place. New York: Routledge.

Ekomadyo, A. S. (2012). Menelusuri "genius loci" pasar tradisional sebagai ruang sosial urban di Nusantara. Semesta Arsitektur Nusantara. Malang: Universitas Brawijaya.

Koentjaraningrat. (1974). Kebudayaan, mentalitet dan pembangunan. Jakarta: Gramedia.

Norberg-Schulz, C. (1980). Genius loci:Towards a phenomenology of Architecture. London: Academy Editions London.

Sufi, R., \& Wibowo, A. B. (2004). Budaya masyarakat Aceh. Banda Aceh: Badan Perpustakaan Provinsi Nanggroe Aceh Darussalam.

Zahnd, M. (1999). Perancangan kota secara terpadu: Teori Perancangan Kota dan penerapannya. Yogyakarta: Penerbit Kanisius. 